\title{
Evaluasi Komposisi Zat Gizi dan Senyawa Antioksidan Kedelai Hitam dan Kedelai Kuning
}

Nurrahman

Program Studi Teknologi Pangan Fakultas IImu Keperawatan dan Kesehatan Universitas Muhammadiyah Semarang, Semarang

Korespondensi dengan penulis (nurrahman@unimus.ac.id)

Artikel ini dikirim pada tanggal 20 Desember 2014 dan dinyatakan diterima tanggal 24 Januari 2015. Artikel ini juga dipublikasi secara online melalui www.journal.ift.or.id. Hak cipta dilindungi undang-undang. Dilarang diperbanyak untuk tujuan komersial.

Diproduksi oleh Indonesian Food Technologists $®$ @2015 (www.ift.or.id)

\begin{abstract}
Abstrak
Kedelai merupakan salah satu bahan pangan yang penting bagi masyarakat Indonesia, yang dikonsumsi untuk memenuhi kebutuhan zat gizi protein. Kedelai dikonsumsi masyarakat sebagai lauk dan camilan. Tujuan penelitian ini untuk membandingkan zat gizi kedelai hitam dengan kedelai kuning. Kedelai dari ketiga varietas sebelum dianalisa terlebih dahulu dihancurkan untuk dibuat tepung kedelai. Tepung kedelai yang diperoleh diayak dengan saringan ukuran 60 mesh. Analisa yang dilakukan meliputi analisa proksimat, asam amino, asam lemak, antosianin dan isoflavon (daidzein dan genistein). Ketiga varietas kedelai memiliki kandungan kimia yang menjadi parameter penelitian kecuali antosianin. Antosianin hanya ada di kedelai hitam, sedangkan kedelai kuning tidak terdeteksi. Ketiga varietas sama-sama mengandung 14 asam amino.
\end{abstract}

Kata kunci: kedelai, zat gizi dan antioksidan

\section{Pendahuluan}

Kedelai merupakan salah satu bahan pangan yang penting bagi masyarakat Indonesia. Masyarakat khususnya ekonomi menengah ke bawah mengandalkan kedelai untuk memenuhi kebutuhan zat gizi protein. Kedelai dikonsumsi masyarakat sebagai lauk dan camilan. Beberapa jenis olahan makanan yang berasal dari kedelai antara lain tempe, tahu, kecap, kedelai goreng, tepung kedelai, susu kedelai, kedelai rebus dan rempeyek. Menurut cerita yang ada di Serat Sentini (1814 Masehi) kedelai yang ada pada saat itu adalah kedelai hitam. Kedelai hitam sering digunakan sebagai bahan hiasan dalam pembuatan tumpeng di masyarakat Jawa. Diduga kedelai hitam merupakan bahan utama pertama kalinya tempe diproduksi oleh masyarakat Jawa (Astuti, 1996).

Tanaman kedelai hitam termasuk famili Leguminosae, subfamili Papilonideae. Kedelai hitam berasal dari China, kemudian dikembangkan di berbagai negara di Amerika Latin, juga Amerika Serikat dan negara-negara di Asia. Di Indonesia, penanaman kedelai hitam berpusat di Jawa, Lampung, Nusa Tenggara Barat, dan Bali. Ada beberapa varietas kedelai hitam antara lain Mallika, Cikuray dan KDL H1 yang selama ini sudah banyak dibudidayakan oleh petani. Varietas kedelai hitam yang dibudidayakan di Jepang adalah Black Jet, dan Hokkaido Black. Sementara RRC, punya varietas kedelai hitam Tainan 3. Balitbang Departemen Pertanian telah mengembangkan kedelai hitam varietas Detam 1 dan Detam 2. Sekarang ini sedang dikembangkan kedelai hitam varietas Detam 3 Prida dan Detam 4 Prida (Anonim, 2013).

Meski lebih rendah dibandingkan dengan kedelai kuning, kedelai hitam juga merupakan sumber protein nabati. Rata-rata kandungan protein biji 37 persen, kandungan asam amino terbanyak adalah tirosin. Kedelai hitam umumnya digunakan sebagai bahan pembuat kecap atau campuran untuk rempeyek maupun bahan camilan. Di daerah Purbalingga Jawa Tengah, kedelai hitam juga digunakan sebagai bahan baku tempe.

Sebagai bahan utama kecap, kedelai hitam memiliki keunggulan tersendiri karena kandungan gizinya yang cukup tinggi, terutama protein dan karbohidrat. Asam amino yang terdapat pada kedelai hitam antara lain leusin dan lisin. Keduanya merupakan asam amino yang sangat diperlukan oleh enzim pemecah kedelai untuk menghasilkan kecap dengan cita rasa yang enak, lezat dan khas. Kedelai hitam juga mengandung asam glutamat lebih tinggi dibanding kedelai kuning. Asam amino tersebut merupakan komponen yang membentuk citarasa lezat (gurih) (Anonim, 2008).

Kedelai kuning impor banyak digunakan sebagai bahan baku tempe. Sebenarnya varietas kedelai unggul yang ditanam di Indonesia juga dapat digunakan untuk pembuatan tempe, tetapi masyarakat lebih banyak mengunakannya untuk pembuatan tahu. Demikian pula dengan kedelai hitam, dilihat dari potensi zat gizi dan produksi tidak jauh dari kedelai kuning, bahkan sifat fungsional lebih tinggi. Kedelai hitam mempunyai kandungan fenolik, tanin, antosianin dan isoflavon serta aktivitas antioksidan lebih tinggi dibanding kedelai kuning ( $\mathrm{Xu}$ dan Chang, 2007). Menurut Xu dan Chang (2007) kedelai hitam kandungan flavonoidnya 6 kali lebih banyak dibanding kedelai kuning (kandungan total flavonoid kedelai kuning dan hitam berturut-turut 0,41 dan $2,57 \mathrm{mg}$ ekuivalen dengan katekin per gram) dan aktivitas antioksidan 15 kali lebih tinggi (DPPH scavenging capacity kedelai kuning dan hitam berturut-turut 1,40 dan 17,58 $\mu \mathrm{mol}$ ekuivalen Trolox per gram). Sedangkan menurut Astadi et al. (2009) kulit kedelai hitam varietas Mallika memiliki kandungan antosianin $1,36 \mathrm{~g} / 100 \mathrm{~g}$ dan senyawa fenolik $6,46 \mathrm{~g} / 100 \mathrm{~g}$. Penelitian ini bertujuan untuk membandingkan zat gizi 
kedelai hitam dengan kedelai kuning sehingga diketahui potensi sifat fungsional kedelai hitam.

\section{Materi dan Metode \\ Materi}

Bahan yang digunakan dalam penelitian ini adalah kedelai hitam varietas Mallika, kedelai kuning import (tidak diketahui varietasnya), kedelai kuning varietas Grobogan, standar genistein (Sigma), standar daidzein (Sigma), dan berbagai bahan kimia untuk analisa proksimat, asam amino, asam lemak, antosianin dan isoflavon.

\section{Metode}

Evaluasi terhadap komposisi zat gizi dan senyawa antioksidan dilakukan pada tiga varietas kedelai yang terdiri dari kedelai hitam varietas Mallika, kedelai kuning varietas Grobogan dan kedelai kuning impor. Kedelai dari ketiga varietas sebelum dianalisa terlebih dahulu dihancurkan untuk dibuat tepung kedelai. Tepung kedelai yang diperoleh diayak dengan saringan ukuran 60 mesh. Analisa yang dilakukan meliputi analisa proksimat (AOAC, 2005), asam amino (AOAC, 2005), asam lemak (AOAC, 2005), antosianin (AOAC, 2005) dan isoflavon (daidzein dan genistein) (Penalvo et al., 2004).

\section{Analisa Asam Amino}

Analisa asam amino dari kedelai dan tempe dengan menggunakan metode HPLC (AOAC, 2005). Persiapan sampel dilakukan dengan menimbang 2-5 mg protein sampel ke dalam tabung reaksi pyrex berukuran $18 \times 150 \mathrm{~nm}$ yang telah dicuci terlebih dahulu dengan $\mathrm{NaOH}$ encer, dibilas dan dikeringkan dalam oven. Selanjutnya dimasukan $1 \mathrm{ml} \mathrm{HCl} 6 \mathrm{~N}$ dan dibekukan dalam es aseton. Setelah membeku dilakukan pengeluaran udara agar kondisi vakum, kemudian dibekukan dan divakumkan lagi. Prosedur tersebut diulangi satu lagi. Jika terdapat gelembung udara ditambahkan 1-2 ml n-oktil alkohol, tabung divakumkan lagi selama 20 menit dan ditutup secara rapat. Setelah suhu mencapai suhu ruang ditempatkan ke dalam oven pada $110^{\circ} \mathrm{C}$ selama $22-24$ jam. Dilakukan pendinginan, kemudian dipindahkan ke labu evaporator. Tabung dicuci dengan $2 \mathrm{ml} \mathrm{0,01} \mathrm{N} \mathrm{HCl}$, dipindahkan ke labu evaporator (Pekerjaan ini diulang 2-3 kali). Isi dari labu evaporator dikeringkan dengan evaporator dalam kondisi vakum. Dalam keadaan kering ditambahkan air destilat deionisasi $10-20 \mathrm{ml}$, pengeringan dilanjutkan sampai kering. Setelah kering ditambahkan $10 \mathrm{ml} \mathrm{HCl} 0,01 \mathrm{~N}$, dan larutan tersebut siap diinjeksikan ke HPLC.

\section{Analisa Asam Lemak}

Analisis asam lemak dilakukan pertama-tama dengan mengekstrak minyak tempe terlebih dahulu dengan larutan dietil eter. Satu gram tempe dihancurkan ditambahkan eter, ektraksi dengan metode soxhlet. Destilat yang terbentuk dikeringkan sampai menghasilkan minyak tempe. Minyak tempe dilarutkan dalam hexan sehingga menghasilkan larutan $5 \%$.
Enam $\mathrm{ml}$ larutan dipipet ke dalam tabung reaksi, kemudian ditambahkan larutan $150 \mathrm{uL} 2 \mathrm{~N}$ methanolik $\mathrm{KOH}$. Campuran tersebut dikocok selama 5 menit dan disentrifus pada $3000 \mathrm{rpm}$ selama 5 menit. Supernatan yang diperoleh dianalisa segera dengan GLC (AOAC, 2005).

Kondisi untuk kromatografi: Kolom bahan kemasan $10 \%$ DGES, temperatur kolom $150-200^{\circ} \mathrm{C}$, temperatur Injektor $240{ }^{\circ} \mathrm{C}$, aliran gas $\mathrm{N}_{2} 40 \mathrm{ml} / \mathrm{min}$, aliran gas $\mathrm{H}_{2} \quad 0,9 \mathrm{~kg} / \mathrm{cm}^{2}$, rang $10^{2}$, atenuasi 32 , kecepatan kertas $5 \mathrm{~mm} / \mathrm{min}$ dan ukuran sampel 1,0 ul.

\section{c. Pengujian Konsentrasi Antosianin}

Ekstrak ditimbang sebanyak 10-15 gram ke dalam labu volumetrik $50 \mathrm{ml}$, kemudian dilarutkan dengan aquades sampai tanda batas. Sebanyak masing-masing 0,1 sampel dimasukan ke dalam dua tabung reaksi. Tabung reaksi pertama ditambahkan larutan buffer potasium klorida $0,025 \mathrm{M}(\mathrm{pH}$ 1) sebanyak 4,95 $\mathrm{ml}$ dan tabung reaksi kedua ditambahkan larutan buffer sodium asetat $0,4 \mathrm{M}(\mathrm{pH}$ 4,5) sebanyak 4,95 $\mathrm{ml}$. Absorbansi dari kedua perlakuan $\mathrm{pH}$ diukur dengan spektrofotometer pada panjang gelombang $520 \mathrm{~nm}$ dan $700 \mathrm{~nm}$ setelah didiamkan selama 15 menit (AOAC, 2005). Pigmen antosianin (sianidin-3-glukosida equivalen, $\mathrm{mg} / 100 \mathrm{~g}$ ) dihitung dengan menggunakan rumus $A \times M W \times D F x$ $10^{3}$ dibagi dengan $\varepsilon \times 1$ (A berarti absorbansi $A_{520}-$ $A_{700}$ pada $\mathrm{pH} 1,0$ dikurangi dengan $A_{520}-A_{700}$ pada $p H$ 4,5 , MW adalah moleculer weight $=449,2 \mathrm{~g} / \mathrm{mol}$ untuk cyd-3-glu, DF adalah faktor pengenceran, dan 1 adalah pathlength dalam $\mathrm{cm}, \varepsilon$ adalah koefisien ekstingensi molar sianidin-3-glukosida sebesar 26.900)

\section{Analisa Profil Isoflavon}

Sampel sebanyak 100 gram dihancurkan, kemudian dikeringkan pada suhu $40^{\circ} \mathrm{C}$ dan dihancurkan lagi. Bubuk sampel 1-2 gram diekstrak dengan $5 \mathrm{ml} 1$ $\mathrm{M} \mathrm{HCl}$ di dalam $80 \%$ etanol dan diinkubasi selama 1 jam pada suhu $80^{\circ} \mathrm{C}$. Selanjutnya di shaker selama 2 menit dan disentrifus 2140 x g selama 2 menit. Supernatan disaring, sedangkan ampas ditambah 2,5 $\mathrm{ml} 80 \%$ etanol kemudian dishaker dan disentrifus kembali. Disaring dan supernatan yang diperoleh digabung dengan supernatan pertama (Penalvo et al., 2004).

Kondisi HPLC: HPLC Merk Simadzu, isokratik, volume sampel $20 \mu \mathrm{l}$, kolom: C 18, eluen: methanol dan asetonitril (97:3), detektor: SPD 10A, laju aliran: 1 $\mathrm{ml} / \mathrm{min}$, temperatur: $25-27^{\circ} \mathrm{C}$, panjang gelombang 260 nm dan pompa LC10AD.

\section{Rancangan Percobaan}

Rancangan percobaan dalam penelitian ini adalah rancangan acak lengkap (RAL). Variabel bebas terdiri dari beberapa varietas kedelai (kedelai hitam varietas Mallika, kuning impor dan kuning lokal varietas Grobogan). Analisa dilakukan sebanyak tiga kali. Sedangkan variabel tergantungnya adalah nilai proksimat (kadar air, protein, lemak dan abu), kadar asam amino, kadar asam lemak, total antosianin dan 
Tabel 1. Komposisi kimia beberapa varietas kedelai

\begin{tabular}{lllll}
\hline No & \multicolumn{1}{c}{ Komposisi } & \multicolumn{1}{c}{ Kadar } \\
\cline { 3 - 5 } & & \multicolumn{1}{c}{ Mallika } & \multicolumn{1}{c}{ Grobogan } & \multicolumn{1}{c}{ Impor } \\
\hline 1 & Kadar air (\%) & $10,57 \pm 0,17^{\mathrm{a}}$ & $11,30 \pm 0,37^{\mathrm{b}}$ & $11,09 \pm 0,11^{\mathrm{b}}$ \\
2 & Kadar protein (\%) & $39,09 \pm 0,11^{\mathrm{a}}$ & $42,32 \pm 0,77^{\mathrm{b}}$ & $37,84 \pm 0,35^{\mathrm{c}}$ \\
3 & Kadar lemak (\%) & $14,47 \pm 0,22^{\mathrm{a}}$ & $16,2 \pm 0.78^{\mathrm{b}}$ & $19,31 \pm 0,17^{\mathrm{c}}$ \\
4 & Kadar abu (\%) & $4,12 \pm 0,05^{\mathrm{a}}$ & $4,06 \pm 0,14^{\mathrm{a}}$ & $4,46 \pm 0,14^{\mathrm{b}}$ \\
5 & Kadar antosianin (mg/100 gr) & $222,49 \pm 22,62$ & $\mathrm{tt}$ & $\mathrm{tt}$ \\
6 & Asam lemak (mg/100 gr): & & \\
& a. Asam palmitat & $2,77 \pm 0,18^{\mathrm{a}}$ & $3,85 \pm 0,33^{\mathrm{b}}$ & $4,07 \pm 0,32^{\mathrm{b}}$ \\
& b. Asam stearat & $509,67 \pm 15,52^{\mathrm{ab}}$ & $523,6 \pm 16,52^{\mathrm{a}}$ & $472,86 \pm 31,71^{\mathrm{b}}$ \\
& c. Asam oleat & $1586,85 \pm 35,68^{\mathrm{a}}$ & $1273,72 \pm 37,20^{\mathrm{b}}$ & $1278,13 \pm 41,52^{\mathrm{b}}$ \\
& d. Asam linoleat & $1984,92 \pm 60,62^{\mathrm{a}}$ & $1792,39 \pm 57,84^{\mathrm{b}}$ & $1824,62 \pm 67,93^{\mathrm{b}}$ \\
& e. Asam linolenat & $238,67 \pm 14,56^{\mathrm{a}}$ & $327,58 \pm 10,03^{\mathrm{b}}$ & $258,88 \pm 10,99^{\mathrm{c}}$ \\
& Kadar isoflavon: & & & \\
& a. Genistein (mg/g) & $0,65 \pm 0,07^{\mathrm{a}}$ & $0,40 \pm 0,01^{\mathrm{b}}$ & $0,89 \pm 0,06^{\mathrm{c}}$ \\
& b. Daidzein (mg/g) & $3,67 \pm 0,41^{\mathrm{a}}$ & $2,27 \pm 0,21^{\mathrm{b}}$ & $2,40 \pm 0,08^{\mathrm{b}}$ \\
\hline
\end{tabular}

Keterangan:

- $\mathrm{Tt}=$ tidak terdeteksi

- Tanda huruf berbeda pada baris yang sama menunjukan beda nyata $(p \leq 0,05)$

Tabel 2. Kadar asam amino beberapa varietas kedelai (mg/1 gram kedelai kering)

\begin{tabular}{lllll}
\hline \multirow{2}{*}{ No } & \multicolumn{2}{c}{ Asam amino } & \multicolumn{3}{c}{ Kadar } \\
\cline { 3 - 5 } & & \multicolumn{1}{c}{ Mallika } & \multicolumn{1}{c}{ Grobogan } & Impor \\
\hline 1 & Aspartat & $51,80 \pm 7,29^{\mathrm{a}}$ & $56,79 \pm 7,88^{\mathrm{a}}$ & $43,43 \pm 3,73^{\mathrm{c}}$ \\
2 & Glutamat & $98,75 \pm 14,30^{\mathrm{a}}$ & $95,11 \pm 17,21^{\mathrm{a}}$ & $84,12 \pm 10,01^{\mathrm{a}}$ \\
3 & Serin & $41,41 \pm 13,14^{\mathrm{a}}$ & $34,93 \pm 13,74^{\mathrm{a}}$ & $31,91 \pm 2,36^{\mathrm{a}}$ \\
4 & Histidin & $16,25 \pm 2,40^{\mathrm{a}}$ & $15,08 \pm 3,66^{\mathrm{a}}$ & $16,99 \pm 0,65^{\mathrm{a}}$ \\
5 & Glisin & $2,52 \pm 0,15^{\mathrm{a}}$ & $3,15 \pm 1,16^{\mathrm{a}}$ & $2,63 \pm 0,62^{\mathrm{a}}$ \\
6 & Arginin & $73,27 \pm 13,08^{\mathrm{a}}$ & $70,19 \pm 13,94^{\mathrm{a}}$ & $74,90 \pm 12,43^{\mathrm{a}}$ \\
7 & Alanin & $23,24 \pm 2,47^{\mathrm{a}}$ & $21,56 \pm 2,00^{\mathrm{a}}$ & $29,49 \pm 1,71^{\mathrm{b}}$ \\
8 & Tirosin & $101,84 \pm 13,03^{\mathrm{a}}$ & $96,03 \pm 6,36^{\mathrm{a}}$ & $94,15 \pm 8,97^{\mathrm{a}}$ \\
9 & Metionin & $9,85 \pm 1,66^{\mathrm{a}}$ & $10,45 \pm 2,98^{\mathrm{a}}$ & $11,36 \pm 2,83^{\mathrm{a}}$ \\
10 & Valin & $16,48 \pm 0,16^{\mathrm{a}}$ & $18,36 \pm 0,40^{\mathrm{b}}$ & $9,38 \pm 0,44^{\mathrm{c}}$ \\
11 & Phenilalanin & $19,99 \pm 3,16^{\mathrm{a}}$ & $20,96 \pm 1,59^{\mathrm{a}}$ & $23,04 \pm 4,71^{\mathrm{a}}$ \\
12 & Isoleusin & $14,26 \pm 0,29^{\mathrm{a}}$ & $16,80 \pm 0,37^{\mathrm{b}}$ & $14,19 \pm 0,28^{\mathrm{a}}$ \\
13 & Leusin & $21,31 \pm 2,05^{\mathrm{a}}$ & $22,91 \pm 5,82^{\mathrm{a}}$ & $23,39 \pm 2,74^{\mathrm{a}}$ \\
14 & Lisin & $51,49 \pm 5,98^{\mathrm{a}}$ & $40,13 \pm 8,68^{\mathrm{a}}$ & $53,71 \pm 13,59^{\mathrm{a}}$ \\
\hline
\end{tabular}

Keterangan:

Tanda huruf berbeda pada baris yang sama menunjukan beda nyata $(p \leq 0,05)$

profil isoflavon. Data yang diperoleh dirata-rata dan ditampilkan dalam bentuk tabel, kemudian dibandingkan antar varietas kedelai.

\section{Hasil dan Pembahasan}

Kedelai yang dievaluasi komposisi zat gizi dan senyawa antioksidan terdiri dari tiga varietas, yaitu kedelai hitam varietas Mallika, kedelai kuning varietas Grobogan dan kedelai kuning impor. Parameter yang digunakan untuk menilai komposis zat gizi dan senyawa antioksidan meliputi proksimat, asam lemak, antosianin, isoflavon dan asam amino.

Tabel 1 menunjukan komposisi kimia dari ketiga varietas tersebut. Komposisi kimia meliputi kadar air, protein, lemak, abu, antosianin, asam lemak dan isoflavon. Asam lemak yang dianalisa meliputi asam palmitat, stearat, oleat, linoleat dan linolenat, sedangkan isoflavon yang dianalisa adalah genestin dan daidzein. Asam palmitat dan stearat merupakan asam lemak jenuh dan asam oleat, linoleat dan linolenat adalah asam lemak tidak jenuh (Legninger, 1995). Genestin dan daidzein merupakan isoflavon yang memiliki sifat sebagai antioksidan (Jha, et al., 1997). Isoflavon terutama daidzein dan genistein merupakan komponen kimia yang diduga memiliki sifat fungsional dari kedelai dan produknya menurut beberapa penelitian. Mazur (1998) menyatakan bahwa daidzein dan genistein merupakan phytoestrogen yang mempunyai sifat estrogenik, antiestrogenik, antikarsinogenik, antifungal dan antioksidan. Kedua komponen tersebut dapat berikatan dengan reseptor estrogen, sehingga mampu berperan sebagai hormon estrogen. Beberapa peneliti lain menyatakan bahwa daidzein dan genistein dapat menurunkan resiko penyakit osteoporosis (Fitzpatrick, 2003), kanker 
payudara (Messina dan Wu, 2009), dan arteriosklerosis (Alkhlaghi dan Bandy, 2008).

Berdasarkan Tabel 1 dapat diketahui bahwa ketiga varietas kedelai memiliki kandungan kimia yang menjadi parameter penelitian kecuali antosianin. Evaluasi komposisi zat gizi dan senyawa antioksidan terhadap tiga varietas kedelai, yaitu kedelai hitam varietas Mallika, kedelai kuning varietas Grobogan dan kedelai kuning impor. Kedelai varietas Grobogan merupakan kedelai kuning lokal mempunyai kandungan protein dan asam linolenat paling tinggi dibandingkan varietas lain. Kedelai hitam varietas Mallika memiliki kandungan daidzein, asam oleat dan linoleat paling tinggi dibandingkan varietas yang lain. Kelebihan dari kedelai hitam mengandung antosianin, yang mana senyawa ini tidak dimiliki oleh kedelai kuning baik varietas Grobogan maupun impor. Menurut Astadi et al. (2009), kandungan antosianin kedelai hitam terletak pada kulitnya yang berwarna hitam, dan antosianin pada kulit kedelai hitam mampu menghambat oksidasi LDL secara in vitro. Sedangkan kedelai kuning impor memiliki kandungan paling tinggi pada genestin, kadar lemak, dan kadar abu dibanding varietas lain.

Tabel 2 menunjukan kadar asam amino dari tiga varietas kedelai. Kandungan asam amino yang dapat dideteksi dari varietas Grobogan, Mallika dan impor dengan metode yang telah dilakukan sebanyak 14 jenis. Ketiga varietas kedelai tersebut kadar asam aminonya sebagian besar tidak beda nyata. Kedelai varietas Grobogan mengandung valin dan isoleusin paling tinggi dibanding varietas lain. Kedelai impor kandungan alaninnya paling tinggi dan aspartat paling rendah dibanding varietas yang lain.

Kedelai hitam memiliki kandungan glutamat, serin dan tirosin lebih tinggi dibanding kedelai kuning varietas Grobogan dan impor meskipun perbedaannya tidak signifikan. Glutamat merupakan asam amino yang berperan dalam membentuk citarasa makanan terutama dalam bentuk monosodium glutamat (MSG). Keberadaannya dalam makanan menyebabkan rasa makanan menjadi gurih. Oleh karena itu, kedelai hitam sangat cocok digunakan sebagai bahan baku kecap. Menurut Nurrahman et al. (2012) tempe yang terbuat dari kedelai hitam memiliki rasa lebih disukai dibandingkan tempe kedelai kuning. Hal ini mungkin disebabkan kandungan glutamat pada kedelai hitam lebih tinggi dibanding kedelai kuning.

Kedelai hitam tergolong bahan pangan yang bersifat fungsional. Isu yang menarik kaitan antara kedelai hitam dengan kesehatan adalah adanya komponen isoflavon dan antosianin. Isoflavon terdapat pada kotiledon biji kedelai, sedangkan antosianin terdapat pada kulit kedelai. Bersama dengan vitamin $E$ dan $\beta$-karoten, isoflavon dan antosianin berkontribusi terhadap nilai aktivitas antioksidan. Nurrahman et al. (2012) melaporkan bahwa aktivitas antioksidan kedelai hitam varietas Mallika lebih tinggi dibanding kedelai kuning import. Hal ini mungkin disebabkan kandungan isoflavon kedelai hitam lebih tinggi dibanding kedelai kuning impor (Tabel 1). Di samping itu, adanya antosianin berkontribusi pada aktivitas antioksidan, sedangkan kedelai kuning tidak terdeteksi (Tabel 1). Beberapa manfaat yang sudah dimuat di media dunia maya bahwa kedelai hitam bermanfaat untuk penyembuhan diabetes militus, obesitas, penuaan dini dan osteoporosis.

\section{Kesimpulan}

Ketiga varietas kedelai yaitu kedelai hitam varietas Mallika, kedelai kuning varietas Grobogan dan kedelai kuning import sama-sama memiliki kandungan kimia yang menjadi parameter penelitian kecuali antosianin. Antosianin hanya ada di kedelai hitam, sedangkan kedelai kuning tidak terdeteksi. Ketiga varietas sama-sama mengandung 14 asam amino.

\section{Ucapan Terima Kasih}

Dana penelitian ini sebagian dibiayai oleh Danone Institute Indonesia (DII) tahun anggaran 2011.

\section{Daftar Pustaka}

Akhlaghi, M. And B. Bandy. 2009. Mechanisms of flavonoid protection myocardial againts myocardial ischemia-repurfusion injury. J. Mole and Cel Cardiol., 46: 309-317.

Anonim. 2008. Kedelai Hitam, Supaya Kolesterol Selalu Terjaga http://cybermed.cbn.net.id/cbprtl/ cybermed/detail.aspx $? x=$ Natural+Healing \& $y=c y b$ ermedl11/0|3|104http://cybermed.cbn.net.id/cbprt l/cybermed/detail.aspx? $x=$ Natural+Healing\&y=cy bermedl11l0|3|104 Diakses tanggal 21 September 2008

Anonim. 2013. Detam 3 Prida dan 4 Prida, kedelai hitam berumur genjah. www.litbang.deptan.go.id. Diunduh pada tanggal 4 September 2013.

AOAC. 2005. Official Methods of Analysis of Association of Official Analytical Chemests. AOAC, Inc.Arlington, Virginia.

Astadi, I.R., M. Astuti, U. Santoso and P.S. Nugraheni. 2009. In vitro antioxidant activity of anthocyanins of black soybean seed coat in human low density lipoprotein (LDL). Food Chem., 122: 659-663.

Astuti, M. 1996a. Sejarah perkembangan tempe. Dalam. Sapuan dan N. Soetrisno (eds). 1996. Bunga Rampai Tempe Indonesia, Jakarta, hal. 21-41. Yayasan Tempe Indonesia, Jakarta.

Fitzpatrick, L.A. 2003. Reprint of soy isoflavones: hope or hype?. Mat., 6(1-2): 132-140.

Jha, H.C., S. Kiriakidis, M. Hoppe, and H. Egge. 1997. Antioxidative Constituents of Tempe. Dalam. Sudarmadji et al. (eds.). 1997. Reinventing the Hidden Miracle of Tempe. Proceding International Tempe Symposium, Bali. Yayasan Tempe Indonesia, Jakarta.

Lehninger, A.L. 1995. Dasar-dasar Biokimia. Penerbit Erlangga, Jakarta (Diterjemahkan oleh Tenawidjaja, M.).

Mazur, W.M., J.A. Duke, K. . and S. Rasku. 1998. Isoflavonoids and lignans in legumes: Nutritional and healt aspects in humans. J. Nutr. Biochem,, $9: 193-200$. 
Messina, M. and A.H. Wu. 2009. Perspectives on the soy-breast cancer relation. Am J Clin Nutr., 89:1673 - 1679.

Nurrahman, M. Astuti, Suparmo dan M.H.N.E. Soesatyo. 2012a. Pertumbuhan jamur, sifat organoleptik dan aktivitas antioksidan tempe kedelai hitam yang diproduksi dengan berbagai jenis inokulum. J. Agritech, 32(1):60 - 65 .
Penalvo, J.L., T. Nurmi and H. Adlercreutz. 2004. A simplified HPLC method for total isoflavones in soy products. Food Chem., 87: 297-305.

Xu, B.J. and S.K.S. Chang. 2007. A Comparative study on phenolic profils and antioxidant of legums as affected by extraction solvents. J. Food Sci., 72(2):159-166. 